DOI: 10.17707/AgricultForest.64.1.14

\author{
Jasmina BALIJAGIĆ, Jovan CRNOBARAC, \\ Miodrag JOVANČEVIĆ, Irfan MUJANOVIĆ ${ }^{1}$
}

\title{
THE EFFECT OF VARIETY AND PLANT DENSITY ON POT MARIGOLD FLOWER YIELD (Calendula officinalis L.) IN AGRO-ECOLOGICAL CONDITIONS OF BIJELO POLJE
}

\section{SUMMARY}

Collecting medicinal plants from their natural habitats cannot meet the needs of the increased demand for natural medicinal raw materials in the global market, which caused the expansion of medicinal plants cultivation. This paper deals with the influence of the three varieties of pot marigold; "Plamen Plus", "Bački Petrovac" and "Orange King" in different sowing density on pot marigold yield.

By studying the effects of the variety and plant density on a total yield of fresh inflorescence of marigold, it was found out that variety has a statistically significant effect on yield. The variety "Plamen plus" has achieved the higher yield (5724 $\mathrm{kg} \mathrm{ha}^{-1}$ ) comparing with the other two varieties which did not differ significantly, although the lowest yield was obtained by the variety “Orange King” (3243 kg ha ${ }^{-1}$ ).

Keywords: Calendula officinalis, pot marigold, variety, yield

\section{INTRODUCTION}

Collecting medicinal plants from their natural habitats cannot meet the needs of increased demand for natural medicinal raw materials on the world market. Today the efforts are made to meet these needs by medicinal plants cultivation/plantation coupled with field inspection, in order to obtain healthy, not pesticide contaminated raw material, uniform quality, sufficient quantity and meet the agreed deadlines (Mrđa et al., 2007; Buha, 2012).

Pot marigold (Calendula officinalis L.) is an annual or, less commonly, biennial herbaceous plant. It is successfully cultivated in areas with moderately warm and moderately humid climate. The sowing forecast is, in fact, the forecast of the date when the sowing layer of soil will be warmed up to the biological minimum required for seed germination (Otorepec, 1980). It grows well on poor soils, but does not

\footnotetext{
${ }^{1}$ Jasmina Balijagić (corresponding author: jas.be@t-com.me), Miodrag Jovančević, Irfan Mujanović, University of Montenegro, Biotechnical Faculty, MONTENEGRO, Jovan Crnobarac, University of Novi Sad, Faculty of Agriculture, Republic of SERBIA

Notes: The authors declare that they have no conflicts of interest. Authorship Form signed online.
} 
provide high-quality yields as in deep soils, with average amount of nutrients. The plants grown under optimal conditions have a higher tolerance to stress factors (Kastori et al., 2013). A significant effect of irrigation on marigold yield has been noticed by Pirzada and Shokran (2012). Adamović (2011) raised the possibility of marigold double cropping, while Popovic et al. (2017) indicated the positive effect of marigold cultivation on poor and neglected soils, with extensive cultivation practices and minimal investments. Pot marigold blooms from June until the first strong frosts. The blossoms are orange or yelloworange (Stepanovic et al., 2011). The pot marigold flowers yield depends on locality, variety selection and stand density (Hojden et al., 1990; Biesiada et al., 2006; Crnobarac et al., 2008; Parađiković et al. 2013). Since it, leaves the land early, the pot marigold is a good pre-crop to other cultures in crop rotation (Kišgeci, 2008). For the pot marigold growing, it is necessary to use the seed that gives abundant flower yield, quality flower heads (Calendulae anthodium) or tongue-shaped ray or ligulate flowers (Calendulae flos) rich in active substances, as well as varieties resistant to diseases and pests (Baciu et al., 2010). The pot marigold flower is used in medicine, including the traditional medicine, and in cosmetic industry (Pirzada and Shokran, 2012; Torbaghan, 2012). Even dried flowers of pot marigold should maintain their lovely orange colour. Moreover, it should have a discreet, pleasant scent. The drug must be free of any organic or inorganic additives (Jevđović et al., 2011). It belongs to the oldest medicinal plants that have been used from the ancient times (Król, 2011), but pot marigold is also used for decorating green spaces (parks) and in various floral arrangements (Selaru, 2007).

Pot marigolds are planted out in early spring, usually by mid-April. Crnobarac et. al. (2011) carried out the sowing in the area of Novi Sad on April 13, whereas in the research conducted by Parađiković et al. (2013), sowing was carried out in Brod-Posavina County on 22 May. Sowing date forecast achieves best results when there is a possibility of comparative measurements of meteorological parameters on the production parcel (Otorepec, 1980).

In investigating the influence of variety and plant density on fresh flower yield and dynamics of yield formation per harvest Crnobarac et. al. (2008) reported that, on average for all varieties, the highest yield was achieved at $50 \mathrm{~cm}$ row spacing, and that why we decided to apply the same row spacing. Sowing was done manually at 4.0, 5.0, 6.7 and $10 \mathrm{~cm}$ distances in the row, at a depth of about $3 \mathrm{~cm}$, with two seeds per hill. In 3- 5 leaves phase, plants were thinned to final plant distance in the row (Jaćimović et al., 2007). 
There is a difference in yields of different varieties due to genetic differences between varieties, the influence of the environmental factors as well as the interaction between the genotype and environmental factors. Planting density is one of the important factor affecting yield components. Therefore, the aim of this paper is to show the influence of variety and distance in row on pot marigold yield in agro-ecological conditions of Bijelo Polje (Montenegro).

\section{MATERIAL AND METHODS}

The field experiment was conducted in 2010 at experimental field in Lješnica. Three varieties were investigated: Plamen Plus (from the Czech Republic), Bački Petrovac and Orange King (material originating from Serbia). The crop was sown on 8 May 2010 at $50 \mathrm{~cm}$ spacing between the rows. Due to climatic characteristics at the experimental site, sowing was carried out on 8 May. During the growing season, standard crop maintenance measures were carried out (hoeing, weeding). The flowers were plucked by hand in 7 successive harvest time, beginning from 17 July.

The variance analysis was used to process the obtained results, in line with the plan of setting up the experiment, which was organized as a three factor splitsplit design. The significance of differences between treatments was determined by using the LSD test at the significance threshold of $1 \%$ and $5 \%$.

The experiment was established on weak acid and poor lime soil, very rich in humus with low content of available phosphorus and medium content of available potassium.

The experiment locality is on $650 \mathrm{~m}$ above sea level, with moderate continental type of climate. Unlike the ten-year average, in the year of setting up the experiment, total monthly precipitation in the vegetation period was not uniformly distributed, so that in August it was only $16 \mathrm{~mm}$. In experimental year the highest daily mean and maximum air temperature occur in the seventh month (Table 1). The same as in the long-term average.

Table 1 . The monthly sum of rainfall $(\mathrm{mm})$ and average monthly air temperature $\left({ }^{\circ} \mathrm{C}\right)$ in 2010 at Bijelo Polje

\begin{tabular}{|l|c|c|c|c|c|c|c|c|c|c|c|c|}
\hline Months & I & II & III & IV & V & VI & VII & VIII & IX & X & XI & XII \\
\hline $\begin{array}{l}\text { Total monthly } \\
\text { rainfall }\end{array}$ & 101.3 & 80.0 & 69.7 & 79.8 & 79.6 & 56.2 & 85.1 & 16.0 & 80.0 & 68.4 & 131.1 & 147.3 \\
\hline $\begin{array}{l}\text { Maximum } \\
\text { monthly } \\
\text { temperature }\end{array}$ & 18.0 & 14.8 & 22.8 & 25.6 & 27.9 & 34.1 & 33.9 & 36.0 & 30.6 & 23.2 & 22.8 & 19.5 \\
\hline $\begin{array}{l}\text { Mean } \\
\text { monthly air } \\
\text { temp. }\end{array}$ & -2.4 & -2.2 & 1.4 & 5.8 & 10.5 & 14.4 & 15.6 & 15.0 & 10.8 & 7.2 & 2.2 & -0.6 \\
\hline
\end{tabular}

*Source: Hydrometeorological Institute of Montenegro 


\section{RESULTS AND DISCUSSION}

The analysis of the fresh flowers yields in each harvest indicate that the harvest time did not have statistically significant impact on yield, and yields were stable in all 7 harvests. The lowest yield in our experiment was accomplished in the fourth harvest due to increased air temperature and reduced precipitation (Tab. 1) which is in accordance with statements by Kastori et al. (2013) that, among natural factors, water stress and extreme air temperatures most often affect the plant growth. The yield of flowers in average and in each harvest was the highest on variety Plamen Plus (818 $\mathrm{kg} \mathrm{ha}^{-1}$ ), compared to other two varieties that did not differ significantly.

This is observed as regularity in almost all the harvests. The highest yield in average for all varieties and harvests amounted to $654 \mathrm{~kg} \mathrm{ha}^{-1}$ in a single harvest and it was obtained at the minimum distance in row of $4 \mathrm{~cm}$. It should be emphasized that from the second to the fifth harvest, the effect of plant distance in the row was different, indicating a stronger interaction. Variety Plamen plus in average obtained statistically highest yield in each harvest at $4 \mathrm{~cm}$ distance in row $\left(1000 \mathrm{~kg} \mathrm{ha}^{-1}\right)$, and variety Orange king at $6.7 \mathrm{~cm}$ distance in row, whereas distance in row did not have a statistically significant effect on the variety Bački Petrovac.

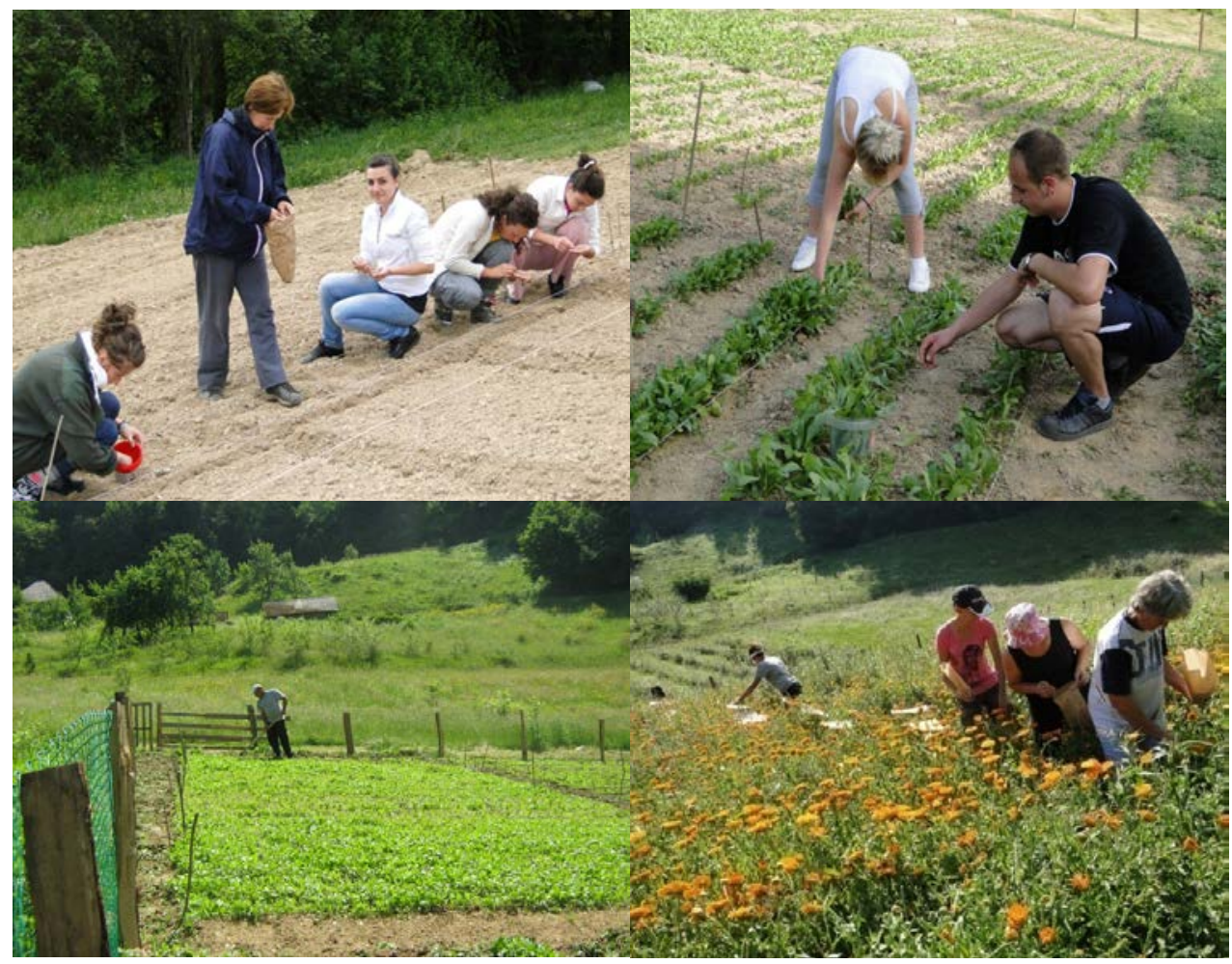

Figure 1. The application of agro-technical measures during the experiment (Photo: Jasmina Balijagić) 
Table 2. Effect of harvest time, variety and distance in row on pot marigold fresh flower yield (kg/ha)

\begin{tabular}{|c|c|c|c|c|c|c|c|}
\hline \multirow{3}{*}{ Harvest (H) } & \multirow{3}{*}{ Variety (V) } & \multirow{2}{*}{\multicolumn{4}{|c|}{ Distance in row cm (D) }} & \multirow{3}{*}{ Average $\mathbf{H V}$} & \multirow{3}{*}{$\begin{array}{c}\text { Average } \\
\boldsymbol{H}\end{array}$} \\
\hline & & & & & & & \\
\hline & & 4 & 5 & 6.7 & 10 & & \\
\hline \multirow{4}{*}{1} & PLAMEN PLUS & 1221 & 1061 & 619 & 1216 & 1029 & \multirow{4}{*}{643} \\
\hline & BAČKI PETROVAC & 898 & 245 & 550 & 713 & 602 & \\
\hline & ORANG KING & 349 & 117 & 457 & 267 & 298 & \\
\hline & Average HD & 823 & 474 & 542 & 732 & & \\
\hline \multirow{4}{*}{2} & PLAMEN PLUS & 909 & 752 & 740 & 1218 & 905 & \multirow{4}{*}{629} \\
\hline & BAČKI PETROVAC & 544 & 236 & 522 & 482 & 446 & \\
\hline & ORANG KING & 576 & 172 & 869 & 528 & 536 & \\
\hline & Average HD & 676 & 386 & 710 & 743 & & \\
\hline \multirow{4}{*}{3} & PLAMEN PLUS & 1027 & 532 & 694 & 784 & 759 & \multirow{4}{*}{590} \\
\hline & BAČKI PETROVAC & 469 & 820 & 655 & 527 & 618 & \\
\hline & ORANG KING & 358 & 271 & 577 & 368 & 394 & \\
\hline & Average HD & 618 & 541 & 642 & 560 & & \\
\hline \multirow{4}{*}{4} & PLAMEN PLUS & 286 & 732 & 832 & 803 & 663 & \multirow{4}{*}{510} \\
\hline & BAČKI PETROVAC & 274 & 677 & 362 & 657 & 493 & \\
\hline & ORANG KING & 206 & 273 & 721 & 291 & 373 & \\
\hline & Average HD & 255 & 561 & 638 & 584 & & \\
\hline \multirow{4}{*}{5} & PLAMEN PLUS & 904 & 862 & 500 & 678 & 736 & \multirow{4}{*}{549} \\
\hline & BAČKI PETROVAC & 510 & 912 & 299 & 434 & 539 & \\
\hline & ORANG KING & 296 & 718 & 168 & 313 & 374 & \\
\hline & Average HD & 570 & 831 & 322 & 475 & & \\
\hline \multirow{4}{*}{6} & PLAMEN PLUS & 1213 & 604 & 475 & 790 & 771 & \multirow{4}{*}{561} \\
\hline & BAČKI PETROVAC & 330 & 123 & 316 & 444 & 303 & \\
\hline & ORANG KING & 639 & 658 & 557 & 584 & 610 & \\
\hline & Average HD & 727 & 462 & 449 & 606 & & \\
\hline \multirow{4}{*}{7} & PLAMEN PLUS & 1440 & 515 & 664 & 825 & 861 & \multirow{4}{*}{643} \\
\hline & BAČKI PETROVAC & 494 & 224 & 216 & 730 & 416 & \\
\hline & ORANG KING & 788 & 435 & 824 & 557 & 651 & \\
\hline & Average HD & 907 & 391 & 568 & 704 & Average $\boldsymbol{V}$ & \\
\hline \multirow{4}{*}{ Average VD } & PLAMEN PLUS & 1000 & 722 & 646 & 902 & 818 & \multirow{4}{*}{$\underline{589}$} \\
\hline & BAČKI PETROVAC & 503 & 462 & 417 & 570 & 488 & \\
\hline & ORANG KING & 459 & 378 & 596 & 415 & 462 & \\
\hline & Average $\boldsymbol{D}$ & 654 & 521 & 553 & 629 & & \\
\hline
\end{tabular}

\begin{tabular}{|r|c|c|c|c|c|c|c|}
\hline LSD & Harvest & Variety & Distance & $\begin{array}{c}\text { Harvest* } \\
\text { Variety }\end{array}$ & $\begin{array}{c}\text { Harvest* } \\
\text { Distance }\end{array}$ & $\begin{array}{c}\text { Variety* } \\
\text { Distance }\end{array}$ & $\begin{array}{c}\text { Harvest* } \\
\text { Variety* } \\
\text { Distance }\end{array}$ \\
\hline $1 \%$ & 237 & 148 & 130 & 384 & 370 & 242 & 638 \\
\hline $5 \%$ & 173 & 111 & 99 & 289 & 280 & 183 & 484 \\
\hline $\begin{array}{l}\text { F } \\
\text { probability }\end{array}$ & 0.591 & $<.001$ & 0.027 & 0.082 & $<.001$ & 0.002 & \\
\hline
\end{tabular}


Table 3. Effect of variety and distance in row on pot marigold fresh flower total yield of all harvests

\begin{tabular}{|l|r|r|r|r|r|}
\hline \multirow{2}{*}{ Variety (V) } & \multicolumn{4}{|c|}{ Distance in row (D) } & \multirow{2}{*}{$\begin{array}{c}\text { Average } \\
\text { V }\end{array}$} \\
\cline { 2 - 5 } & 4 & 5 & 6.7 & 10 & $\mathbf{5 7 2 4}$ \\
\hline PLAMEN PLUS & 7000 & 5057 & 4524 & 6314 & $\mathbf{5 4 1 5}$ \\
\hline BAČKI PETROVAC & 3519 & 3237 & 2920 & 3987 & $\mathbf{3 4 1}$ \\
\hline ORANG KING & 3212 & 2644 & 4173 & 2908 & $\mathbf{3 2 3 4}$ \\
\hline Average D & $\mathbf{4 5 7 7}$ & $\mathbf{3 6 4 6}$ & $\mathbf{3 8 7 2}$ & $\mathbf{4 4 0 3}$ & \\
\hline
\end{tabular}

\begin{tabular}{|c|c|c|c|}
\hline LSD & Variety & Distance & Variety* Distance \\
\hline $1 \%$ & 820 & 886 & 1444 \\
\hline $5 \%$ & 541 & 656 & 1075 \\
\hline F probability & $<.001$ & 0.023 & 0.023 \\
\hline
\end{tabular}

The study of the effects of the variety and plant density on a total fresh flowers yield of all harvests (Table 3 ) has shown that the variety has a statistically significant effect on yield. Variety Plamen plus had a significantly higher yield (5724 kg ha ${ }^{-1}$ ), in relation to other two varieties which did not differ significantly, although the variety "Orange king” obtained the lowest yield (3243 $\mathrm{kg} \mathrm{ha}^{-1}$ ). Crnobarac et.al. (2008) also found that fresh flowers yield in average and on each row spacing was the highest on variety Plamen Plus. Although there were significant differences in yield affected by distance in row, there is no general regularity of its effect, due to the high interaction with varieties. Namely, the variety Plamen plus gave significantly highest yield at $4 \mathrm{~cm}$ distance in row, variety Orang king at $6.7 \mathrm{~cm}$ distance in row, while distance in row did not significantly affect the variety Bački Petrovac, although the yield was highest at $10 \mathrm{~cm}$ distance. A significant effect of plant density on yield was also determined by Parađiković et al. (2013).

\section{CONCLUSIONS}

According to field experiment data of influence of variety and distance in row on pot marigold yield in agro-ecological conditions of Bijelo Polje it could be made following conclusions.

The municipality of Bijelo Polje represents area of hills and valleys along the rivers and this environment enable plantation and economically feasible yields of pot marigold flowers.

The highest yield in average was recorded by variety Plamen plus, at all applied distances in row. Variety Plamen Plus obtained the highest yield at $4 \mathrm{~cm}$ distance in row.

\section{REFERENCES}

Adamović.S. D. (2011): Variation of inflorescence yield and total careened content as relatide to harvest data of the stubble organic production of pot marigold. Bilten za 
alternativne biljne vrste, Vol. 43.No. 84, 43-47. Institut za ratarstvo i povrtarstvo, Novi Sad.

Baciu, A.D., L. Mihalte, A. Sestras And R. Sestras (2010). Variability of Decorative Traits, Response To The Aphis Fabae Attack And RAPD Diversity In Different Genotypes Of Calendula. Notulae Botanicae Horti Agrobotanici Cluj-Napoca 38(3):265 -270.

Biesiada A., Sokół - Łętowska A., Kucharska A.,Wołoszczak E., 2006. Wpływ Formy I Dawki Azotu na Plonowanie I Skład Chemiczny Koszyczków Nagietka (Calendula Officinalis L.). / The Effect Of Form And Rate of Nitrogen On Yielding And Chemical Composition Of Pot Marigold (Calendula Officinalis L.) Flower Heads. Foliahort. 18, Supl.1: 61-65 (In Polish).

Buha, Milica (2012): Lekovito, začinsko i aromatično bilje u komercijalnoj upotrebi.Udruženje za lekovito bilje "Dr Jovan Tucakov" Sokobanja.

Crnobarac, J., Jaćimović, G., Marinković, B., Mircov,V.D., Mrđa, J., Babić, M. (2008): Dynamics of PotMarigold Yield Formation Depended by Varieties and Row Distance. Humeiul si Plantele Medicinale 31(1-2):116-121

Crnobarac, J., Marinković, B., Jaćimović, G., Latković,D., Balijagić, J. (2011): The effect of cultivar and stand density on yield components and yield of pot marigold. Acta fytotechica et zootechnica 1: 6-8

Hojden B., Lamer -Zarawska E., Świąder K. (1990): Przydatność herbicydów w pielęgnacji nagietka lekarskiego (Calendula officinalis L.). / Usefulness of herbicides in culture of pot marigold (Calendula officinalis L.). Herba Pol. 1\2: 57 (in Polish).

Jaćimović, G., Mrđa, Jelena, Marinković, B., Crnobarac,J. (2007.): Proizvodni potencijal čeških sorata nevena u proizvodnim uslovima Vojvodine. Letopis naučnih radova 31(1): 140.-145.

Jevđović, R., Kostić, M., Todorović, G. (2011):Sušenje lekovitog bilja. Institut za proučavanje lekovitog bilja „Dr Josif Pančić“" Beograd

Kastori, R., Ilin, Ž., Maksimović, Ivana, Delić-Putnik, Marina (2013): Potassium in plant nutrition - potassium and plant vegetables. Faculty of Agriculture, University of Novi Sad.

Kišgeci, J. ( 2008): Lekovite i aromatične biljke. Partenon Beograd i Srpska književna zadruga Beograd.

Król Beata (2011):The Effect Of Different Nitrogen FertilizationRates On Yield And Quality Of Marigold(Calendula Officinalis L. 'Tokaj') Raw Material. Acta Agrobotanica, Vol. 64 (3): 29-34.

Mrđa, Jelena, Marinković, B., Jaćimović, G. (2007):Effect of row spacing on calendula (Calendula officinalisL.) flowers production. Research Journal of Agricultural Science 39(1): 77-82.

Otorepec, Silvia ( 1980): Agrometeorologija. Nolit, Beograd 1980.

Parađiković Nada, Vinković T., Baličević Renata, Tkalec Monika, Ravlić Marija, Kokanović Anita (2013): Effects of planting space and harvest time on the number, weight and diameter of marigold (Calendula officinalis L.) flowers. Poljoprivreda 19:2013 (2) 23-28. ISSN 1330-7142

Pirzad Alireza and Shokrani Fahime (2012): Effects Of Iron Application On Growth Characters AndFlower Yield Of Calendula Officinalis L. Under Water Stress. World Applied Sciences Journal 18 (9): 1203-1208

Popović S., Jovin Slobodanka, Đuranović D., Popović Vera, Filipović V., IvanovićMunitlak Olja, Grubješić Ž., Mijić R.(2017): The importance of planting pot 
marigolds (Calendula officinalis L.) in degraded public spaces from the agroecological and economic perspective. Contemporary Agriculture Vol. 66, No. 1-2, Pp. 27-31.

Selaru, E., (2007): Variability Of Decorative Traits, Response To The Aphis Fabae Attack and Rapid Diversity In Different Genotypes Of Calendula. S.265-270.

Stepanović B., Radanović D. (2011): Tehnologija gajenja ljekovitog i aromatičnog bilja u Srbiji. Institut za proučavanje ljekovitog bilja "Dr Josif Pančić", Beograd

Torbaghan E.M. (2012): Effect Of Salt Stress On Germination And Some Growth Parameters Of Marigold (Calendula Officinalis L.) Plant Science Journal, 1(1): 07-19, 2012. 